\title{
NOTES
}

\section{CHOICE OF LAW: FEDERAL GOVERNMENT'S SUIT TO COLLECT LOAN GRANTED BY FEDERAL AGENCY DEFEATED BY STATE LAW DEFENSE OF COVERTURE}

$U_{\text {NDER THE Erie doctrine federal courts are required to apply state }}$ law to determine the outcome of litigation where the matter involved is not expressly governed by the federal constitution or acts of Congress. ${ }^{1}$ In suits where the United States is a party to a commercial instrument, however, the exercise of a constitutional function or power may often render Erie inapplicable in determining the Government's rights and duties. ${ }^{2}$ If a federal rule is thus required, state law cannot control unless incorporated as an appropriate source of federal common law. Without articulating the basis for its choice of law, the Fifth Circuit in United States $v$. Yazell ${ }^{3}$ held that a Texas law invalidating most married women's contracts was a valid defense to a deficiency judgment on a loan executed to the Small Business Administration (SBA).

In Yazell, the defendant and her husband (trading as a partnership) had signed a promissory note to repay money borrowed as a disaster loan from the SBA.4 After default by the husband and defendant, the federal government foreclosed on a chattel mortgage and subsequently sued for a deficiency judgment against both

${ }^{1}$ Erie R.R. v. Tompkins, 304 U.S. 64 (1938). See generally WRIGHT, FEDERAL CoURTs 187-218 (1963); Clark, State Law in the Federal Courts: The Brooding Omnipresence of Erie v. Tompkins, 55 YALE L.J. 267 (1946).

Some courts have limited the application of Erie to diversity cases, See, e.g., United States v. View Crest Garden Apts., Inc., 268 F.2d 380, 382 (9th Cir.), cert. denied, 361 U.S. 884 (1959); American Textile Mach. Corp. v. United States, 220 F.2d 584, 587 (6th Cir. 1955); Sands v. United States, 198 F. Supp. 880, 883 (W.D. Wash. 1960), aff'd sub nom., 295 F.2d 481 (9th Cir. 1961). Contra, 1A MOore, FeDeral Pracrice I 0.305[3], at 3052-57 (1961) (the law to be applied is keyed to the nature of the issue rather than the jurisdictional basis). For non-diversity cases in which Erie was applied, see cases cited id. at 3055 n.7. For the application of federal law in a diversity case, see American Pipe \& Steel Corp. v. Firestone Tire \&: Rubber Co., 292 F.2d 640, 644 (9th Cir. 1961).

2 Clearfield Trust Co. v. United States, 318 U.S. 363 (1943). See generally Dumbauld, The Glear Field of Clearfield, 61 DrCK. L. Rev. 299 (1957); 53 Colum. L. REv. 991 (1953).

s 334 F.2d 454 (5th Cir. 1964), cert. granted, 85 S. Ct. 651 (1965) (No. 575).

Id. at 456 . 
obligors. Although the federal district court entered a judgment against the husband, it held that under Texas law a contract to which a married woman is a party is unenforceable as to her separate property. The Cuurt of Appeals for the Fifth Circuit affirmed on the ground that one incapable of making a contract cannot be held liable merely because the United States was a party to the instrument. $^{6}$

After Erie announced that there was no federal general common law, ${ }^{7}$ the federal courts applied state law in cases where the federal government was a party to a commercial instrument. ${ }^{8}$ In Clearfield Trust Co. v. United States, ${ }^{\circ}$ however, the Supreme Court decided that Erie was inapplicable in determining the rights and duties of the United States on a forged government check, because the authority to issue such checks was derived from "the Constitution and the statutes of the United States."10 The Court reasoned that application of state law would subject the Government's legal rights to "exceptional uncertainty," 11 and would render identical transactions subject to the "vagaries of the laws of the several states."12 Thus there emerged an area of "federal common law"13 pursuant to the Clearfield mandate that "in absence of an applicable Act of Congress it is for the federal courts to fashion the governing rule of law according to their own standards."14 In cases involving government contracts, ${ }^{15}$ government issue of commercial paper, ${ }^{16}$ and execution

\footnotetext{
${ }^{5}$ See 13 VERnoN's ANN. Crv. ST, art. 4623 (1960). The article has since been repealed. Acts 1963, ch. $472 \S 4$.

- The dissenting judge contended that the defense of coverture should not have been allowed, for "a loan from the Federal Government is a federal matter and should be governed by federal law.... This is the clear holding of [Clearfield]." 334 F.2d at 456. He did not indicate from what source the federal law abrogating coverture would be derived, but argued that "the federal rule ought to be that you must repay what you borrow." Ibid.

704 U.S. at 78.

${ }^{3}$ See, e.g., Alameda County v. United States, 124 F.2d 611 (9th Cir. 1941) (contract); United States v. Brookridge Farm, Inc., 111 F.2d 461 (10th Cir. 1940) (contract); Live Stock Nat'l Bank v. United States, 106 F.2d 241 (7th Cir. 1939) (insurance policy); Security-First Nat'l Bank v. United States, 103 F.2d 188 (9th Cir. 1939) (government check); Keifer \& Keifer v. RFC, 97 F.2d 812 (8th Cir. 1938) (contract). See Pofcher, The Choice of Law, State or Federal, in Cases Involving Government Contracts, $12 \mathrm{LA}$. L. REv. 37, 38-42 (1951); 40 CoRNeli L.Q. 561, 566 (1955).

- 318 U.S. 363 (1943).

${ }^{10} \mathrm{Id}$. at 366 .

"Id. at 367 .

12 Ibid.

1s United States \& Standard Oil Co.. 332 L.S. 301308 (1947).

1" 318 L.S. at $36 \%$.

${ }^{15}$ E.g., Priebe \& Sons v. ( nited States, 332 U.S. 407 (1947); United States v. Standard
} 
of commercial instruments to the government, ${ }^{17}$ the rights and liabilities of the United States acting on its own behalf or through one of its agencies has often been determined by federal common law if there is no controlling act of Congress.

In determining whether federal law should apply to these cases, the courts have considered the following criteria: whether the activity of the Government was authorized by a Constitutional function or power; ${ }^{18}$ the existence of relevant federal statutes; ${ }^{18}$ and the presence of a sufficient federal interest. ${ }^{20}$ In these instances, Erie has no effect on matters which vitally affect the interests, powers and relations of the United States requiring uniform national disposition. ${ }^{21}$ Once federal law is deemed controlling, the courts may refer to several sources to determine the appropriate federal rule, ${ }^{22}$ including federal case law, ${ }^{23}$ the Negotiable Instruments Law, ${ }^{24}$ the

Rice Co., 323 U.S. 106 (1944); United States v. County of Allegheny, 322 U.S. 174 (1944); United States v. Taylor, 333 F.2d 633 (5th Cir. 1964); United States v. Chester Park Apartments, Inc, 332 F.2d 1 (8th Cir. 1964); Reimann v. United States, 815 F.2d 746 (9th Cir. 1963); Krupp v. Federal Housing Administration, 285 F.2d 833 (1st Cir. 1961); American Houses, Inc. v. Schneider, 211 F.2d 881 (3d Cir. 1954).

Even before Clearfield, federal law was held applicable in a few government contract cases for this reason. See Royal Indemnity Co. v. United States, 313 U.S. 289, 296 (1941) (federal right is not dependent on state remedy); Byron Jackson Co. v. United States, 35 F. Supp. 665 (S.D. Cal. 1940). See generally Pofcher, supra note 8.

${ }^{16}$ E.g., National Metropolitan Bank v. United States, 323 U.S. 454 (1945); Clearfield Trust Co. v. United States, 318 U.S. 363 (1943); Fulton Nat'l Bank v. United States, 197 F.2d 763 (5th Cir. 1952); Continental-American Bank \& Trust Co. v. United States, 161 F.2d 935 (5th Cir. 1947), cert. denied, 338 U.S. 870 (1949). See generally Comment, 6 VILL. L. REv. 388 (1961).

${ }^{17}$ E.g., United States v. Helz, 314 F.2d 301 (6th Cir. 1963); Hendry v. United States, 305 F.2d 515 (9th Cir. 1962); New York, N.H. \& H.R.R. v. RFC, 180 F.2d 241 (2d Cir. 1950); W. T. Jones \& Co. v. Foodco Realty, Inc., 206 F. Supp. 878 (W.D. Va. 1962). See generally Comment, 6 VrL.. L. REv. 388 (1961).

18 United States v. County of Allegheny, 322 U.S. 174, 182 (1944); Clearfield Trust Co. v. United States, 318 U.S. 363, 366 (1943); United States v. McCabe, 261 F.2d 539, 543 (8th Cir. 1958); Sands v. United States, 198 F. Supp. 880, 882 (W.D. Wash. 1960), aff'd sub nom. 295 F.2d 481 (9th Cir. 1961); United States v. United States Foreign Corp., 151 F. Supp. 658, 659 (S.D.N.Y. 1957); FDIC v. Rectenwall, 97 F. Supp. 273, 274 (N.D. Ind. 1951).

${ }^{10}$ United States v. View Crest Garden Apts., Inc., 268 F.2d 380, 382 (9th Cir.), cert. denied, 361 U.S. 884 (1959); W. T. Jones \& Co. v. Foodco Realty, Inc., 206 F. Supp. 878, 885 (W.D. Va. 1962). See also Mitchell v. Flintkote Co., 185 F.2d 1008, 1011 (2d Cir.), cert. denied, 341 U.S. 931 (1951) (executive order).

${ }^{20}$ United States v. Taylor, 333 F.2d 633, 637 (5th Cir. 1964); United States v. Sommerville, 324 F.2d 712, 714 (3d Cir. 1963); American Houses, Inc. v. Schneider, 211 F.2d 881, 883 (3d Cir. 1954).

21 United States v. Standard Oil Co., 332 U.S. 301,307 (1947).

${ }^{22}$ See 46 MINN. L. REv. 975, 980-81 (1962).

${ }^{28}$ E.g., National Metropolitan Bank v. United States, 323 U.S. 454, 456 (1945); Clearfield Trust Co. v. United States, 818 U.S 363. 367 (1943): United States v. 
Uniform Sales $A c t,{ }^{25}$ and Restatements. ${ }^{28}$ Provisions of state law may also be adopted or incorporated as the federal rule when considered adequate to accomplish the required federal policy or when consistent with adequate protection of the federal interest. ${ }^{27}$

Since the United States was suing to enforce a promissory note to which it was a party, the result in Yazell can only be justified as either: ( 1 ) the application of Erie due to the absence of a sufficient federal interest or policy; 28 or (2) the incorporation of Texas law as the appropriate federal rule.

Although the Fifth Circuit distinguished Clearfield on its facts, ${ }^{29}$

Sommerville, 324 F.2d 712, 717 (3d Cir. 1963); United States v. Matthews, 244 F.2d 626 (9th Cir. 1957); Girard Trust Co. v. United States, 149 F.2d 872, 874 (3d Cir. 1945); Boy v. United States, 179 F. Supp. 67, 69 (M.D.N.C. 1959). The courts frequently refer to general contract law. E.g., Priebe \& Sons v. United States, 332 U.S. 407, 411 (1947) (liquidated damages); United States v. Standard Rice Co., 323 U.S. 106, 111 (1944) (revision of contract); Guy F. Atkinson Co. v. Merritt, Chapman \& Scott Corp., 141 F. Supp. 833, 837 (N.D. Cal. 1956), aff'd, 295 F.2d 14 (9th Cir. 1961) (indemnification agreement in construction contract).

24 E.g., Hendry v. United States, 305 F.2d 515, 518 (9th Cir. 1962) (methods for discharge of negotiable instrument); New York, N.H. \& H.R.R. v. RFC, 180 F.2d 241, 244 (2d Cir. 1950) (legal effect of offer to reduce interest on notes).

${ }^{20}$ See Whitin Mach. Works v, United States, 175 F.2d 504, 507 (1st Cir. 1949) (implied warranty under contract for sale of goods).

${ }^{20}$ See United States v. Le Roy Dyal Co., 186 F.2d 460, 461 (3d Cir. 1950) (RestateMENT, CONTRACTS $\$ 339$ (1932) (liquidated damages).

${ }^{27}$ Clearfield Trust Co. v. United States, 318 U.S. 363, 367 (1943); United States v. Union Live Stock Sales Co., 298 F.2d 755, 758 (4th Cir. 1962); Bumb v. United States, 276 F.2d 729, 736-37 (9th Cir. 1960); cf. United States v. Standard Oil Co., 332 U.S, 301, 308-10 (1947), where it was suggested that state law might be incorporated in the following types of cases: (l) when the Government purchases real estate from one whose title to the property is invalidated by state law; (2) when it appears that Congress has consented to the application of state law; and (3) when state law may furnish "convenient solutions" not inconsistent with adequate protection of the federal interest. The court indicated that relevant considerations include: federal supremacy in the performance of federal functions; the need for uniformity; and inferences to be drawn from the silence of Congress.

${ }^{28}$ For cases in which federal law was rejected see RFC v. Breeding, 211 F.2d 385 (10th Cir. 1954) (action by federal corporation held not comparable to suit by United States as a sovereign); United States v. Covington Independent Tobacco Warehouse Co., 152 F. Supp. 612, 614 (E.D. Ky. 1957) (court considered itself bound to apply state law under the Erie doctrine); see Werfel v. United States, 83 F. Supp. 507 (S.D.N.Y. 1948) (state law applied because contract executed in state); cf. United States v. Bryant, 58 F. Supp. 663 (S.D. Fla. 1945), aff'd, 157 F.2d 767 (5th Cir. 1946) (application of state law was favorable to the government).

In some cases federal law is held to govern one issue, state law held to govern another. Bank of America v. Parnell, 352 U.S. 29 (1956) (state law governed the qucstion of "good faith." federal law governed the question of whether the bonds were overdue); Continental Cas. Co. v. Schaefer, 173 F.2d 5 (9th Cir. 1949). See generally Comment, 6 Vil... L. Rev. 388 (1961); 45 CAlif. L. ReV. 212 (1957); 18 U. PitT. L. REV 820 (1957).

${ }^{20} 334$ F.2d at 455 . The court held that this was not like those cases "of federal 
the theory of that decision has been extended to other factual settings ${ }^{30}$ including those where the United States sues to enforce a promissory note executed to a federal agency. ${ }^{81}$ The disaster loans which the SBA administers to small business constitute the exercise of a function authorized by the Constitution and federal statutes..$^{32}$ In Bumb v. United States, ${ }^{33}$ the Ninth Circuit held that this authorization alone was sufficient to require the application of federal common law in determining the validity of chattel mortgages executed to the SBA.

Similarly, in a suit to foreclose mortgages insured by the Federal Housing Administration (FHA), the Sixth Circuit in United States v. Helz $z^{34}$ also found federal law to be applicable because that agency's lending activity was authorized by statute. That decision, however, went beyond the analysis offered in Bumb and evaluated the federal interest in preserving the money and credit of the Government, and the policy of protecting federal investments to facilitate the building of homes. Since the FHA and SBA both operate through local offices for the benefit of financially distressed citizens, the success of both programs requires that the United States be able to collect loans and protect its investments. The only major difference between the two agencies is the ultimate use of their loans, thus, the interest and policy of the Government in enforcing repayment of FHA loans would seem to apply to the SBA as well. In light of the constitutional and statutory authorization for lending activities, the policy of aiding small business, and the federal interest in collection, the better view would appear to be that Yazell is not a proper case for the Erie requirement of state law.

The result reached by the Fifth Circuit, therefore, is justifiable only if Texas law of coverture can be incorporated as an appropriate

commercial paper issued by and as an obligation of tbe United States," but was merely a simple case of whether a married woman could be held liable on a contract which "she was incapable of making."

so See cases cited notes 15 and 17 supra.

s1 See, e.g., United States v. Helz, 814 F.2d 301 (6th Cir. 1968) (note originally executed to a bank, but subsequently acquired by the FHA, which succeeded to the bank's rights); Hendry v. United States, 305 F.2d 515 (9th Cir. 1962).

82 Disaster loans are authorized by an amendment to the Small Business Act of 1953. 69 Stat. 549 (1955), 15 U.S.C. $\$ 686($ b) (1958). The underlying constitutional authority appears to rest on the commerce clause. See Small Business Act of $1958 \S$ 202, 67 Stat. 232, 15 U.S.C. $\$ 631$ (1958).

s8 276 F.2d 729 (9th Cir. 1960).

s 314 F.2d 801 (6th Cir. 1963). 
source for determining the federal rule. In deciding whetler state law should be adopted instead of an independent federal rule, ${ }^{35}$ some lower federal courts have balanced the state and federal interests. ${ }^{36}$ Thus they have evaluated the federal interest in uniform rights and duties and effective remedies to protect the security of federal investments, as against state procedural safeguards and policy.

Generally, local law is deemed inconsistent with the appropriate federal rule when it frustrates the remedies of the Government ${ }^{37}$ as opposed to merely stipulating procedures to be followed in effectuating a valid transaction. ${ }^{38}$ In $B u m b$, therefore, the local recording statute was applied because it did not purport to preclude the Government's remedy in foreclosing a validly created security interest. The requirement of filing notice for the benefit of other creditors did not inhibit the Government's right to require security for its loans. In $\mathrm{Helz}$, however, state law of coverture was rejected ${ }^{39}$ as a valid defense because it prohibited any recovery on a note executed by the defendant. Arguably, the Texas law in Yazell was merely a procedure and not frustration of a remedy because a mar-

${ }^{35}$ In United States v. Standard Oil Co., 332 U.S. 301, 309 (1947), the Court stated that state law may be applied when Congress has so consented. In Bumb v. United States, 276 F.2d 729 (9th Cir. 1960), the court found no congressional intent to exempt requirements for SBA loans from local law. Id. at 736 .

${ }^{30}$ See United States v. View Crest Garden Apts., Inc., 268 F.2d 380 (9th Cir.), cert. denied, 361 U.S. 884 (1959), where the court stated, "A court confronted with [the question of redemption, for example]... could determine it by weighing the federal interest against the particular local policy involved. If the considerations weighed by the court suggest an adoption of local law, such as the local rule on redemption, that could be done. But if on the other hand necessity requires the fashioning of a federal rule, absent a declared federal rule on the subject the federal courts are authorized to and capable of fashioning one." Id. at 383. See Bumb v. United States, note 35 supra; WrIGHT, FEDERAI COURTS 216-17 (1963); Mishkin, The Variousness of "Federal Law": Competence \& Discretion in the Choice of National \& State Rules for Decision, 105 U. PA. L. REv. 797, 810-14 (1957).

${ }^{87}$ United States v, Helz, 314 F.2d 301 (6th Cir. 1963). In United States v. View Crest Garden Apts., Inc., note 36 supra, the court stressed that when remedies are involved the federal policy to protect the Treasury and to promote the security of federal investment is paramount.

${ }^{88}$ Bumb v. United States, 276 F.2d 729 (9th Cir. 1960); United States v. View Crest Garden Apts., Inc., 268 F.2d 380, 383 (9th Cir.), cert. denied, 361 U.S. 884 (1959) (dictum).

${ }^{30}$ The defendant and her husband had executed two notes to a banking institution to secure a loan for improvements on their home. Prior to the making of the loan, they had provided for FHA payment insurance under the National Housing Act. After a default, the notes were assigned to the United States on behalf of the FHA. Since the husband had been discharged in bankruptcy, the United States sought to recover from the wife. 314 F.2d at 302 . The court fashioned an independent federal rule which disallowed the common law defense of coverture in Michigan and provided for enforcement of the obligation. Id. at 303 . 
ried woman was enabled by statute to waive the contractual disability afforded by coverture. ${ }^{40}$ Thus, the federal government could have collected its loans by requiring the defendant to waive her protection. Nonetheless, the Fifth Circuit relied upon another theory by asserting that the defendant's disability invalidated her contractual liability from its inception, in the same manner accorded contracts of a person of minor age or unsound mind. Under this rationale, the remedy-procedure dichotomy is not presented because a legal obligation was never incurred.

This analogy to the law governing persons of minor age or unsound mind, however, fails to satisfy the federal interest in uniform rules governing the disposition of federal rights and duties on commercial instruments. ${ }^{41}$ Uniformity facilitates the effective administration of federal loans by obviating the necessity of tailoring loan programs to the law and policy of each state. A fundamental distinction between the recording requirement in $B u m b$, the disability of minors and persons of unsound mind on the one hand, and the Texas law of coverture on the other, is that the former represent policies to which all states adhere; ${ }^{42}$ the disability of married women is an archaic common law concept remaining only in a few states..$^{43}$ Since the SBA is involved in the extension of credit on a nationwide

\footnotetext{
to Under Texas law any married woman could have applied by written request to a district court for an order removing her disability. If it appeared to the court that waiver would have been to the applicant's advantage, the court could have entered its decree declaring her capable of contracting for mercantile or trading purposes. 18 VERNON's ANN. CIV. ST. art. 4626 (1960). The provision has since been amended, Acts 1963 , ch. $472 \& 6$, and the repeal of article 4623 has rendered article 4626 nugatory. See note 5 supra.

41 See, e.g., Clearfield Trust Co. v. United States, 318 U.S. 363 (1943); United States ๑. Sommerville, 324 F.2d 712 (3d Cir. 1963); Sands v. United States, 198 F. Supp. 880 (W.D. Wash. 1960), aff'd sub nom. First Federal Sav. \& Loan Ass'n v. United States, 295 F.2d 481 (9th Cir. 1961); Guy F. Atkinson Co. v. Merritt, Chapman \& Scott Corp., 141 F. Supp. 833 (N.D. Cal. 1956), aff'd, 295 F.2d 14 (9th Cir. 1961). The dissenter in Yazell stated that uniform application of the Small Business Act was necessary to insure the repayment of large sums of money. He contended that the general applica. tion of local rules as to contractual capacity would result in "chaos which would nullify federal programs for disaster relief..." 334 F.2d at 456. Furthermore, he argued that the decision of the majority could not be limited to the Small Business Act, but would frustrate a multitude of other federal programs. Ibid.

12 In Bumb the court noted the general enactment of laws requiring notice of intent to mortgage and stated that no hardship would be imposed on the SBA under such a rule, "in the light of the fact the policy of all states of the Union is to give to such creditors some modicum of protection." 276 F.2d at 738.

18 See 26 AM. JUR. Husband \& Wife $\$ 20$ (1940), which states that the disability of a wife to act and contract as a legal person has been removed in practically all states.
} 
basis, this type of variant law is a prime example of the evil which has necessitated the application of uniform federal rules.

Nevertheless, there are compelling reasons for asserting that the federal interest in uniformity is inconsistent with the administration of loans by the SBA. As the Ninth Circuit recognized in Bumb, this agency operates on a local basis with local personnel who should be aware of laws of the state in which they work. ${ }^{44}$ Since the administration of such loans involves many contractual and property questions governed by state law, the agency would not be overburdened by recognizing the Texas policy supporting coverture. ${ }^{45}$ Furthermore, alert SBA officials could have easily required the defendant in Yazell to waive her contractual disability as a condition to the loan. ${ }^{46}$ Aside from these factors, the application of a well-established body of local law would also provide the prospective borrower with a greater degree of certainty as to his individual rights and obligations. An independent federal rule drawn from disparate sources of lawi leaves both parties in doubt; many sources of law would have to be checked to insure the protection for which each party bargains.

Much of the confusion reflected in the Yazell, Bumb and Helz decisions could be eliminated if Congress adopted the Uniform Commercial Code as the exclusive source of federal law. ${ }^{45}$ In those

"In $B u m b$ the court stated that although the SBA operates throughout the United States "such fact raises no presumption of the desirability of a uniform federal rule with respect to the validity of chattel mortgages in pursuance of the lending program...." 276 F.2d at 738.

4 For a discussion of the Texas policy on married women's contracts see Red River Nat'1 Bank v. Ferguson, I09 Tex. 287, 206 S.W. 923 (1918). The court stated, "the steady unbroken policy of the laws of Texas has been to protect the property of the wife from the debts of the husband." Id. at 924. The court explained, "if [the wife's] powers have been restricted, her property, at least, has been safeguarded. The limitations upon her authority are but the expression of a scrupulous concern for the preservation of her estate, and were imposed to that end. In that interest her authority to contract debts at all was confined to those essentially to her advantage, that is, for necessaries for herself or her children and the benefit of her estate...." Id. at 925. See Tolbert v. Standard Acc. Ins. Co., 148 Tex. 235, 223 S.W.2d 617 (1949).

'See note 40 supra.

17 For the various sources utilized see notes 23-26 supra.

18 See Friendly, In Praise of Erie-and of the New Federal Common Law, 19 RECoRD of N.Y.C.B.A. 64 (1964), suggesting that such adoption might meet the desire for uniformity. However, Judge Friendly states that it would be difficult to determine the scope of the enactment: "Should such a federal rule apply only to transactions where the papers or the goods they represent cross state lines? Should it exhaust the commerce power by one of the traditional wordings or adopt the suggested form of covering "every case where there is some basis for applying the law of more than one state?' Should it go even further and also include all commercial contracts with the federal government, all such contracts sought to be enforced in admiraltw, even all 
states which have already adopted the Code, ${ }^{40}$ the prospective borrower would not be faced with a different rule when dealing with federal agencies. But until the Code is adopted by legislative enactment or judicial decree, the local activities of such federal agencies as the SBA tend to justify choice of law decisions incorporating state law whenever possible.

such contracts passing through the mail. Or should Congress take the bolder step of declaring that in order to make its rule truly workable in these large areas of its enumerated powers, the small remaining enclaves must also be occupied." Id. at 90-91.

4 The Code has been adopted in 30 jurisdictions. UnIForm CoMmercial Code, UNIF. LAWS ANN. 5 (Supp. 1964). 